Review Article

\title{
A STUDY TO ASSESS THE PREVALENCE AND ATTITUDE OF USE OF TOBACCO PRODUCTS AMONG ADOLESCENT BOYS
}

\author{
Sarita Fernandes ${ }^{1}$, Suchithra B.S. ${ }^{2}$ \\ ${ }_{1 \ltimes 2} 2$ Lecturer, Department of Community Health Nursing, Nitte Usha Institute of Nursing Sciences, \\ Nitte University, Deralakatte, Mangalore - 575018. \\ Correspondence: \\ Sarita Fernandes \\ Lecturer, Department of Community Health Nursing, Nitte Usha Institute of Nursing Sciences, \\ Nitte University, Deralakatte, Mangalore - 575018.
}

\begin{abstract}
:
A simple descriptive design was adopted for the study to assess the attitude among the adolescent regarding tobacco consumption. The sample consisted of 100 adolascents boys, Convenient sampling method was used to select the samples. The data collection for the study was done by using demographic performa, questionnaire and rating scales. The analysis of the data was based according to the objectives and hypothesis. The results showed that- M ajority of the consumers 57 (57\%) were between the age group of 16-19 years of age , 39 (39\%) were have secondary education, Attitude of adolescent boys towards to bacco consumption is negative (32\%). There was no association between attitude and demographic variable like age, education and economic status etc $(p \varangle 0.05)$.

Smoking of cigarettes, particularly of "beedies" (which consist of about 0.2 to $0.3 \mathrm{~g}$ of tobacco rolled up in the leaf of another plant (tambourine) has been widespread for many decades among men in India. There have, however, been no substantial studies on the prevalence of tobacco use among youth in India. The tobacco prevalence among girls is alarming. The results of survey show the need to increase awareness about health hazards of tobacco use amongstudents.
\end{abstract}

Keywords: adolescent boys, tobacco, attitude prevalence

\section{Introduction:}

Tobacco is an agricultural product, which is commonly consumed as a recreational drug. Tobacco consumption is a global problem among the adolescents. It is one of the chief preventable causes of death in the world. ${ }^{1}$

Tobacco is consumed, especially in India and south East Asian countries, through Chewing. Chewing tobacco is a risk factor for oral cancer.The annual incidence of oral cancer in men in India is estimated to be 10 per 10000. Regardless of how tobacco is consumed, its adverse influence on disease and mortality among Individual's populations is clear. Tobacco consumption is often found to

\begin{tabular}{|c|}
\hline Access this article online \\
\hline Quick Response Code \\
\hline
\end{tabular}

be disproportionality higher among lower socioeconomic groups. The tobacco consumption has direct and indirect effect on health. Epidemiological research has been focused primarily on cigarette/tobacco, smoking, which has been studied more extensively than any other form of consumption. ${ }^{1}$

Tobacco use leads most commonly to diseases affecting the heart and lungs. Smoking remains a major risk factor of heart attack, strokes, COPD, and cancer (particularly lung cancer, cancer of larynx, mouth and pancreatic cancer). It also causes peripheral vascular diseases and Hypertension. The effect depends on the number of years that a person smokes and how much the Person smokes. ${ }^{2}$ In rural areas of Karnataka $1.6 \%$ of males and $19.6 \%$ of females is consuming tobacco and in urban area $0.3 \%$ of males and $13.8 \%$ of females is consuming. ${ }^{3}$

In an observational study, it was found that, many of the adolescent are spending their leisure time in smoking. From the estimated survey, it was found that in rural areas of Karnataka $1.6 \%$ of males and in urban $0.3 \%$ of males is consuming tobacco. It was also found that the attitude of adolescent boys towards tobacco consumption is positive. ${ }^{4}$ 


\section{Title of the study:}

A study to assess the prevalence and attitude of use of tobacco products among adolescent boys.

\section{Objectives:}

1. To assess the prevalence of use of tobacco products among adolescent boys.

2. To determine the attitude of adolescent boys towards tobacco consumption in selected rural area of Karkala.

3. To find out the association between the attitude and selected demographic variables.

4. To find out the association between the prevalence and selected demographic variables.

\section{Research methodology :}

Conceptual framework for the study was developed on the basis of Rosenstock's Health Belief Model (1974). To accomplish the objectives of the study, questionnaire was prepared by reviewing the related literature and in consultation with subject experts.

Reliability of the tool was tested by using split half method. Questionnaire was found to be reliable. The research approach adopted for the study was a simple descriptive design which was used to assess the attitude among the adolescent regarding tobacco consumption. Convenient sampling method was used to select the samples. The data collection for the study was done by using demographic performa, questionnaire and rating scales.

\section{Results:}

Analysis of data in general way involves a number of closely related operations which are performed with the purpose of summarizing the collected data, organizing these in such a manner that they answer the research question.

\section{Section 1: Description of sample characteristics}

The present study revealed that out of 100 samples 18 (18\%) of them were in the age group of $12-14 \mathrm{yrs}, 25 \%$ of them were in the age group of 14-16yrs, 57(57\% )of them were in the age group of 16-19yrs.The majority of the subjects $70(70 \%)$ were Hindus, $21(21 \%)$ were M uslims and 9 (9\%) were Christians.The majority of the subjects $39(39 \%)$ were educated above $10^{\text {th }}$ std, $28(28 \%)$ were in $10^{\text {th }}$ std, $20(20 \%)$ in $9^{\text {th }}$ std and $13(13 \%)$ were in $8^{\text {th }}$ std.The majority of the subjects 52 (52\%) were coolie workers, 25 (25\%) were doing business ,8(8\%)farmers and $7(7 \%)$ were professionals and $3(3 \%), 5(5 \%)$ were government employers, other works respectively.The majority of the subjects $45(45 \%)$ were having income below Rs.5000, 33(33\%) were having income between Rs.5,001- 10,000, $11(11 \%)$ were having income Rs.10, 001-15,000, and $11(11 \%)$ were having above Rs.15,000. The majority of the subjects $85(85 \%)$ were not doing part time work, $15(15 \%)$ were doing part time work. The majority of the subjects $54(54 \%)$ of the family members were not consuming tobacco products and $46(46 \%)$ of the family members were consuming tobacco products.The majority of the subjects $64(64 \%)$ belong to nuclear family and $28(28 \%)$ belong to joint family, and $8(8 \%)$ belong to extended family.

\section{Section 2: Analysis of prevalence of tobacco use.}

Table 2: The prevalence of tobacco use among adolescents

\begin{tabular}{|l|c|c|l|}
\hline Prevalence & Frequency & Percentage & Inference \\
\hline $\begin{array}{l}\text { Adolescent boys } \\
\text { with tobacco } \\
\text { consumption }\end{array}$ & 32.00 & 32.00 & $\begin{array}{l}\text { Adolescent boys } \\
\text { with tobacco } \\
\text { consumption } \\
\text { was 32\% }\end{array}$ \\
\hline $\begin{array}{l}\text { Adolescent boys } \\
\text { without tobacco } \\
\text { consumption }\end{array}$ & 68.00 & 68.00 & $\begin{array}{l}\text { Adolescent boys } \\
\text { without tobacco } \\
\text { consumption } \\
\text { was 68\% }\end{array}$ \\
\hline
\end{tabular}

\section{Section 3: Attitude of adolescent boys towards tobacco consumption.}

According to arbitrary classification the attitude of adolescent boys towards tobacco consumption is negative.

\section{Section4: Association between attitude and demographic variable.}

There was no association between attitude and age, religion, education, no. of sibling, order of sibling, income, occupation of mother and father and part time work.

\section{Conclusion:}

The world health organization has described tobacco consumption to be today's most public health problem. 
Present study highlighted tobacco consumption in adolescent boys as an emerging public problem. ${ }^{6}$

Prevention of tobacco consumption in children is easier than the adults. Based on the findings of the study it is recommended that improved family background and educational status can prevent tobacco consumption to a certain limit. This should be encouraged at the primary

\section{Reference :}

1. Gupta M C, Mahajan BK.Text book of preventive and social medicine. $3^{\text {rd }}$ edition. Bombay (India): Jaypee publication; 1972

2. Elder Jaypee, Wildey M.Long term prevention control for tobacco, American journal of public health 2000, Volume 45, PP138-144

3. Lippincott Williams. Family and community health: Indian journal of home health care 2005; Volume 28, PP18-21

4. Rahim Asma.Principles and practice of community medicine. $1^{\text {st }}$ edition, New Delhi (India): J aypee publication; 2008

5. Swanson M.Text book of community health nursing; 2nd edition.California:W B Saunders company; 1997

6. Jeanet Lancaster. Family and community health, Indian journal of home health care 2005, Volume 28, PP18-21

7. Ray Stewart Cecily. Tata institute of fundamental research. American journal of public health 1993, Volume 33, PP1239-1245 level. Health awareness programme should be given to the prone adolescents, school level, and village level and to the community. ${ }^{?}$

This study concluded that Adolescent boys with tobacco consumption was $32 \%$ and Adolescent boys without tobacco consumption was $68 \%$. 